\title{
SCHOOL MATURITY AND READINESS FOR EDUCATION OF BILINGUAL CHILDREN FROM THE PREPARATORY CLASSES FROM VARNA
}

\author{
Porojanova S., M. Atanasova ${ }^{1}$, K. Petrova, K. Yaneva ${ }^{1}$ \\ Department of Hygiene and Disaster Medicine, Prof. Paraskev Stoyanov Medical University \\ of Varna, ${ }^{1}$ Regional Inspection for Protection and Control of Public Health of Varna
}

Reviewed by: Assoc. Prof. V. Iotova

\begin{abstract}
We carried out an observation of the school maturity and readiness for education of 24 bilingual children of gipsy origin and 36 children with mother language - Bulgarian (a control group) from the preparatory classes from Varna. The methods of Bratanova for complex assessment of the school maturity were used. The observation of the school maturity was held at the beginning and at the end of the school year. The complex assessment of the school maturity shows that at the beginning of the school year $95,83 \%$ of the bilingual children are immature and only $4,16 \%$ are with moderate maturity, as in the control group even at the beginning of the year there is a high percentage of mature and moderate mature children $-44,44 \%$. At the end of the school year more significant is the improvement in the physical development, while the indexes of neuro-psychical development, so important for education, stay unsatisfactory.
\end{abstract}

Key words: bilingual children, preparatory classes, school maturity

Children with asymmetric bilinguism, whose mother language is different from the official, often have difficulties in education. The low level of command of the Bulgarian language worsens the communication abilities of the children and can lead to negative attitude to school.

In Bulgaria there is an obligatory pre-school training of children before they start first class. It prepares the children for education, and for the new school requirements. The studies for the pre-school training of the bilingual children in our country are insufficient and incomplete. According to this our aim was to observe and follow in yearly dynamics the school maturity of children whose mother tongue is different from Bulgarian.

\section{FORMULATION AND METHODS}

We carried out an observation of the school maturity and readiness for education of 24 bilingual children of gipsy origin and 36 children with mother language - Bulgarian - a control group from the preparatory classes from Varna. The methods of Bratanova (3) for complex assessment of the school maturity were used, according to them children are divided into school mature, moderate mature and immature. They include a complex of indexes for assessment of the physical and neuro-psychical development of the children. For assessment of the physical development of children are used the indexes - height, body mass and proportions of the body.
The indexes for the neuro-psychical development are mother language, mathematics, painting abilities, auditory and motor memory and stability of attention.

The observation of the school maturity was held at the beginning and at the end of the school year. The results are worked up by variation analysis.

\section{RESULTS AND ANALYSIS}

At the beginning of the school year the average height of the bilingual children is $112,7 \mathrm{~cm}$, and for the control group it is $199 \mathrm{~cm}$. With mark "immature" for this index are 33, 33\% of the bilingual children towards $8,33 \%$ of the control group.

The growth for both groups for the observed period is $3,1 \mathrm{~cm}$.

At the end of the school year the average height is respectively 115,8 and $122,1 \mathrm{~cm}$. Immature at the end of the year for this index are $41,66 \%$ for the bilingual towards $8,33 \%$ for the control group. The differences for both of the groups are statistically reliable $(\mathrm{p}<0,001)$ at the beginning and at the end of the year (Fig. 1).

The body mass of the children is according to the achieved height. Bigger variations are found in the control group, where one child is with obesity, and two children are with overweight body mass. There is no information for obesity between the bilingual children.

The proportions of the body are assessed with the Filipine test of Ziller. At the beginning of the school year immature 
according to this index are $91,66 \%$ of the bilinguals and $75 \%$ of the control group. The improvement of this index is significant at the end of the year - only $29 \%$ of the bilinguals and $8,33 \%$ of the control group do not have proportions of the body near those of adults. The differences in the percentages between the beginning and the end of the school year for both groups are statistically significant $(\mathrm{p}<0,001)$.

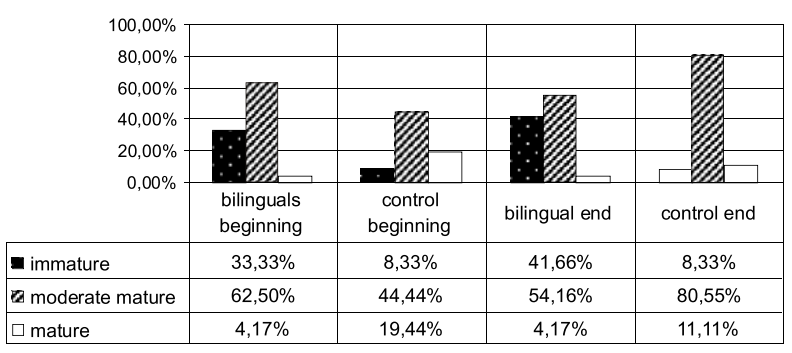

Fig. 1. Physical development

The complex assessment of the physical development shows that between the bilinguals at the beginning of the school year the percentage of children with delayed development is bigger in comparison to the control group $(\mathrm{p}<0,001)$ and this difference stays till the end of the year.

Important role for the successful education has the neuro-psychical development. Nowadays school education is pointed towards development of the intellectual qualities of the person.

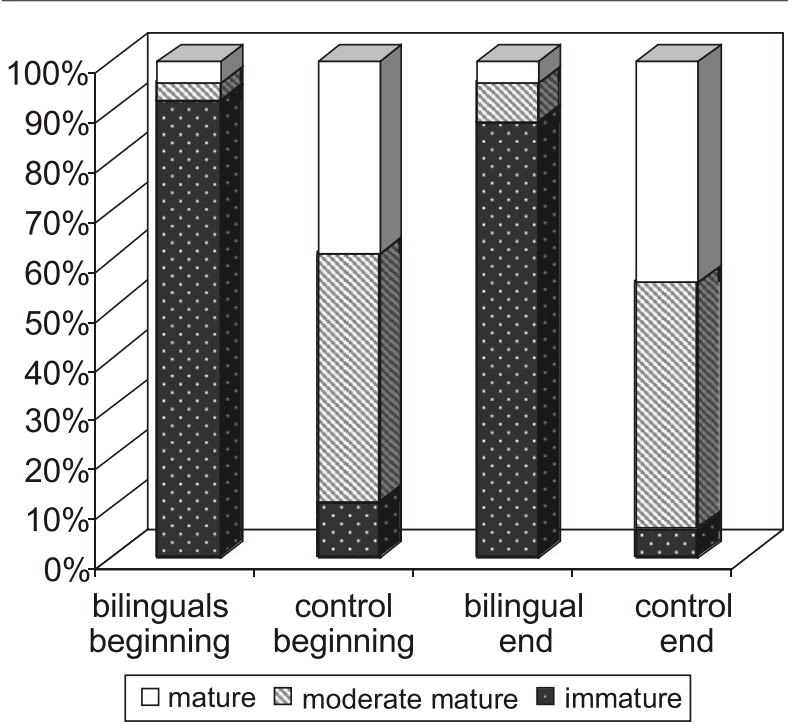

Fig. 2. Index "mother language"

The command of the Bulgarian language is basic for the successful accepting of the school material. By the index "mother language" (Fig. 2) is received the information for the abilities of the bilingual children to use it for communication. At the beginning of the school year $91,65 \%$ of the children with mother language different from Bulgarian are immature according to this index. They answer with difficulty to the given question, usually with single words and improper sentences. $87,5 \%$ of the children stay also immature according to this index at the end of the school year.
The improvement is statistically non significant $(p>0,1)$. Despite the efforts of the teachers the language abilities in Bulgarian do not improve. This disturbs the learning of the material and leads to negative attitude to education.

The mathematics abilities of the bigger part of the bilingual children are insufficient at the beginning of the school year - with the test cope just $8,33 \%$ of the children, $54,16 \%$ of the children can not count. In the control group even at the beginning of the year the mathematic abilities are good ( $47,22 \%$ of the children cope with the test) and only $25 \%$ can not count (Fig.3.1).

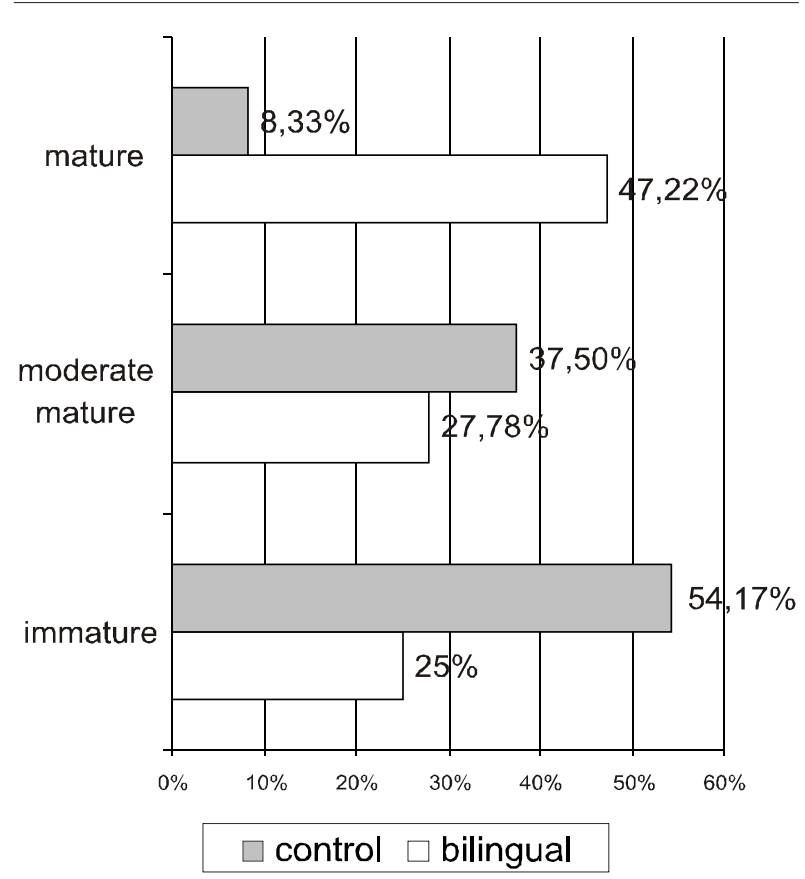

Fig. 3.1. Matematic ablities at the beginning of the school year

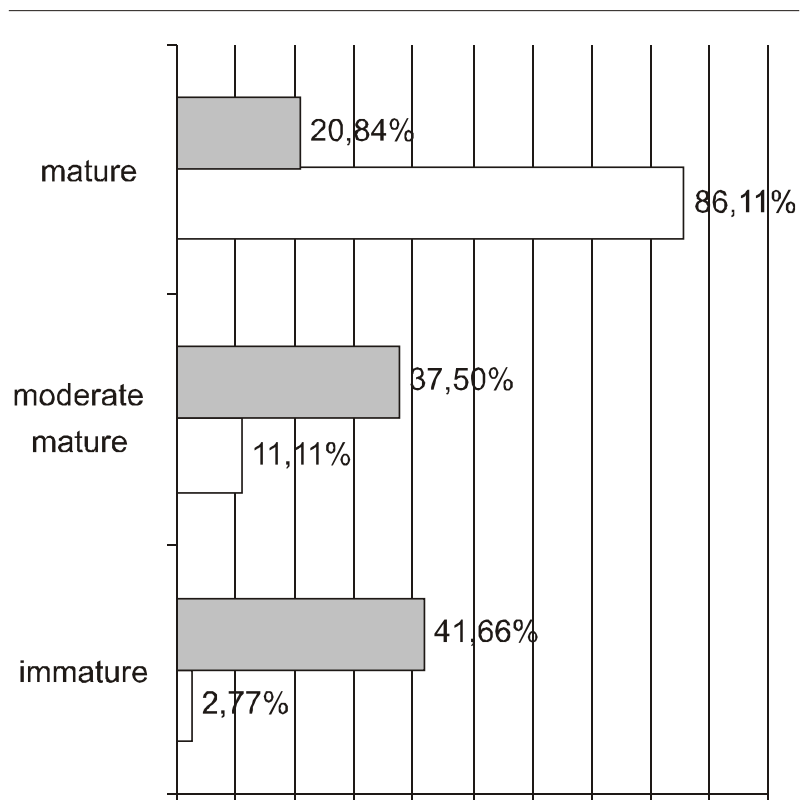

$\begin{array}{lllllllllll}0 \% & 10 \% & 20 \% & 30 \% & 40 \% & 50 \% & 60 \% & 70 \% & 80 \% & 90 \% & 100 \%\end{array}$

$\square$ control $\square$ bilingual

Fig. 3.2. Matematik abilities at the end of the school year 
At the end of the school year the improvement of the bilingual children of their mathematic abilities is insufficient. Still $41,65 \%$ of the children can not count. In the control group just one child can not count $(2,77 \%)$ at the end of the year (Fig.3.2).

The painting abilities are not directly connected with speech, but they depend on the social conditions and the pedagogic stimuli. The painting of a human figure is difficult for the bilingual children. $100 \%$ of the children at the beginning of the year and $92 \%$ of them at the end of the year are immature for this index.

The auditory memory is very important for the education of children. It shows their abilities to remember and reproduce numbers in Bulgarian. At the beginning of the school year $95,86 \%$ of the bilingual children are with insufficient auditory memory, at the end of the year $91,66 \%$. The difference is not statistically reliable $(\mathrm{p}>0,1)$.

The motor memory is important for the developing of writing. For $73,83 \%$ of the children with mother tongue different from the Bulgarian it is insufficient at the beginning of the school year; in the control group this percentage is $30,55 \%$. At the end of the year immature for this index are $66,66 \%$ of the bilinguals and $8,33 \%$ of the control group. The attention of the child in the pre-school ages is a necessary premise for acquiring of knowledge. It has no dynamic features and reflexes the agitative and inhibition processes in the brain cortex. It is being tested with the test of Burdon, with modification of Batoeva.

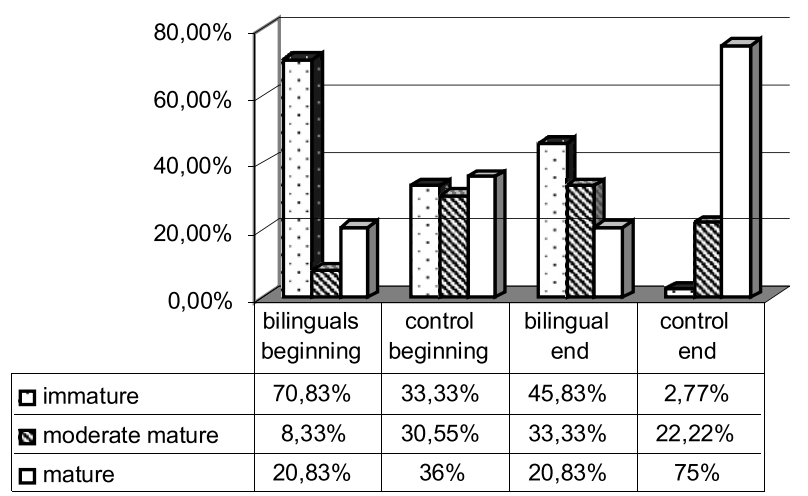

Fig. 4. Index "Stability of attention"

In the bilingual group at the beginning of the year the percentage of immature children according to this index is high $(70,83 \%)$. They show distraction and decrease of the concentration of attention as they make a lot of mistakes and misses. At the end of the year the percentage of the immature children decreases $(45,83 \%)$ at the expense of the moderate maturity. The percentage of the mature bilinguals stays unchanged. In the control group even at the beginning of the year children show good stability of attention, only $1 / 3$ are with assessment "immature" $(33,33)$. At the end of the year because of the pedagogical stimuli they improve their concentration and with assessment "mature" are $75 \%$. Only one child stays immature $(2,77 \%)$. The differences between both groups are statistically reliable $(\mathrm{p}<0,0001)$ at the beginning of the year and at the end. The difficulties in understanding the given task lower the motivation of the bilingual children for the fulfillment of it and from this come most of the mistakes (fig. 4).

The complex assessment of the school maturity shows that at the beginning of the school year $95,83 \%$ of the bilingual children are immature and only $4,16 \%$ are with moderate maturity, as in the control group even at the beginning of the year there is a high percentage of mature and moderate mature children - 44,44\%. At the end of the school year more significant is the improvement in the physical development, while the indexes of neuro-psychical development, so important for education, stay unsatisfactory (Fig. 5).

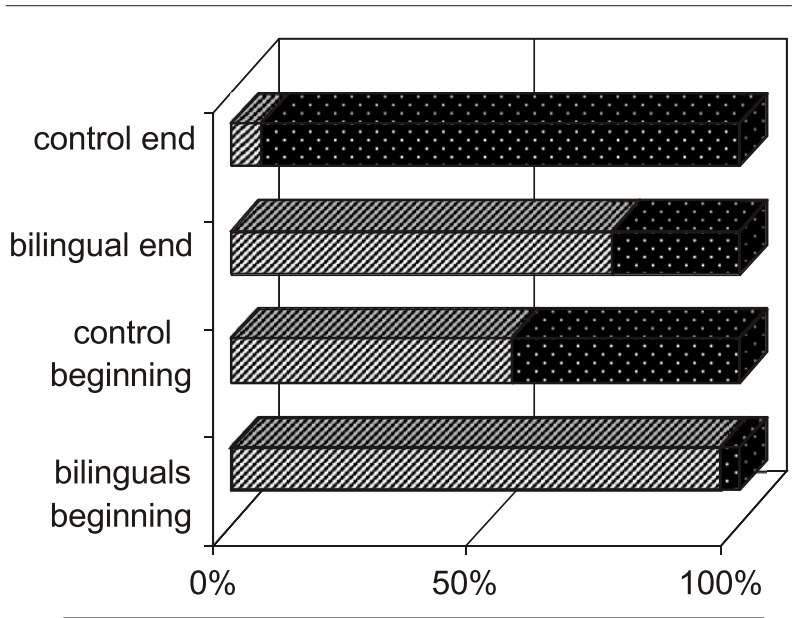

immature $\mathbf{m}$ mature and moderate mature

Fig. 5. School maturity

The lack of knowledge of the language, the difficulties in communication and the lack of interest of the children, disturb their intellectual development and achieving of maturity for education. The use of parents as translators does not solve the problem. In some conditions this may worsen things, because children do not think they have to know Bulgarian. We think that there is a need of a special program for intensive learning of Bulgarian, suitable to the educational requirements of the bilingual children. The need of specific language education and different approach to these children is marked also by other authors $(4,5,6,7)$.

\section{CONCLUSIONS}

1. Children with asymmetric bilinguism start their education in the preparatory classes with low level of school maturity and only $1 / 4$ of them reach school maturity at the end of the year.

2. At the end of the school year improves the physical development of the bilinguals, but their neuro-psychical development stays insufficient

3. There is a need of specific program for education which must be suitable to the specific needs of these children and to lead to improvement of the knowledge of Bulgarian language and development of the psycho-nervous qualities of the person - speech, attention, memory, etc. 
Porojanova S., M. Atanasova, K. Petrova ...

\section{REFERENCES}

1. Ангелова Т. "Ролята на обучението по български език за интегрирането на ученици в двуезична среда" 2003 г.

2. Батоева Д. " Адаптация на децата към обучение" 1983 г.

3. Батоева Д. Колева И. "Диагностика и подготовка за ограмотяване" 1997 г.

4. Батоева Д. "Диагностика на развитието на детето преди постъпването му в училище" 2004 г.
5. Здравкова Ст. "Ограмотяване на децата в условията на билингвизъм" 2004 г.

6. Кючуков X. "Лингодидактични проблеми на обучението при ранен билингвизъм" 2001 г.

7. Кючуков X. "Ранна езикова социализация в условията на билингвизъм" 2002 г.

8. Самоилова М. "Децата от малцинствен произход в условията на билингвизъм" 2002 г.

9. Сотиров П. "Двуезичните деца проблеми ли са за обучението" 2003г. 